\title{
NOTE ON THE ILLUSTRATIONS
}

FRONTISPIECE. Laurence Sterne. In the Ford Collection of the New York Public Library. This drawing closely resembles the first portrait of Sterne by Sir Joshua Reynolds, in the Lansdowne Collection (see the frontispiece to Letters), but it has never been definitely attributed to Reynolds.

PLATE 1 (p. 4). Title page to Vol. I of the first edition of The Sermons of Mr. Yorick.

PLATE 2 (p. 14). Title page to Vol. I of the first edition of Smollett's Travels through France and Italy.

MaP (facing p. 162). Paris au XVIIIe siècle: Plan de Paris ... dessiné et gravé sous les ordres de Michel-Étienne Turgot... levé et dessiné par Louis Bretez, Paris, 1734-1739. (The plate in the present edition is reproduced from a facsimile publ. Paris, 1851.) Yorick's journey to Paris is set in $\mathbf{1 7 6 2}$, the same year as Sterne's first trip there (see p. 192.7-8n, below), and this map agrees in all details relevant to the present edition with Deharme's flat map of Paris, publ. Paris, 1762-1763.

\section{Plates 3-12 follow p. 292.}

PLATE 3. Laurence Sterne. Engraving from the watercolor sketch by Louis Carogis, dit Carmontelle, in the Musée Condé at Chantilly. (The plate in the present edition is taken from the reproduction of the engraving facing p. 308 in Life.) On 19 March 1762 Sterne wrote Garrick from Paris: "The Duke of Orleans has suffered my portrait to be added to the number of some odd men in his collection; and a gentleman [Carmontelle] who lives with him has taken it most expressively, at full length" (Letters, No. 85, pp. 157-158; for Carmontelle, see Letters, p. 159, n. 9).

PLATE 4. Laurence Sterne. Marble replica in the National Portrait Gallery, London, of the bust executed by Joseph Nollekens when Sterne was in Rome in 1766 (see Life, pp. xix, 404). The plate in the present edition is taken from the plate facing p. 404 in Life. 
xii Note on the Illustrations

Plate 5. A désobligeante, as pictured in the edition of A Sentimental Journey published by J. E. Nicholls, London [1840?] (see App. A, p. 296, n. 8).

PLaTe 6. Untitled engraving by Thomas Stothard of the old man lamenting the death of his ass, facing p. 56 in the edition of $A$ Sentimental Journey published by J. Good and E. and S. Harding, London, 1792. Stothard's illustrations for this edition typify the emphasis placed on the sentimental and "pathetic" aspects of the book by illustrators during the period 1770-1800; see T. C. Duncan Eaves, "Graphic Illustration of the Principal English Novels of the Eighteenth Century" (unpubl. dissertation, Harvard, 1944), I, 241-243, 248-249; II, 632-634.

Plate 7. William Bunbury, "A Tour to Foreign Parts" (publ. 1778). From a copy in the British Museum. The young English gentleman (center) is holding a volume entitled "Chesterfield Letters"--presumably Lord Chesterfield's letters to his son, publ. 1774 (see Catalogue of Prints and Drawings in the British Museum, IV, 798-799, No. 4732). (This print is used as frontispiece in Maxwell.)

Plate 8. "The Dance at Amiens," etched by Thomas Rowlandson, facing p. 99 in The Beauties of Sterne: Comprising his Humorous and Descriptive Tales, Letters, \&c. \&c. Embellished by Caricatures, by Rowlandson, from Original Drawings by Newton, published by Thomas Tegg, London, 1809 (from a copy in the Harvard Library). Rowlandson's etchings in this volume are described in Eaves, "Graphic Illustration," I, 257-258; II, 643-644. On Newton's illustrations of $A$ Sentimental Journey, see the note on plate 12, below.

PLATE 9. "Yorick Feeling the Grisset's Pulse," etched by Thomas Rowlandson. Frontispiece to The Beauties of Sterne (see the note on plate 8 , above).

PLATE 10. Untitled engraving by Thomas Stothard of Yorick and Maria, facing p. 162 in the edition of A Sentimental Journey described in the note on plate 6 , above. 
PLATE 11. Untitled engraving by Thomas Stothard of "The Grace," facing p. 175 in the edition of $A$ Sentimental Journey described in the note on plate 6 , above.

PLATE 12. "The Grace," etched by Richard Newton, facing p. 174 in Sterne's Sentimental Journey through France and Italy, with Twelve Illustrative Prints, Designed and Etched by Richard Newton, published by William Holland, London, 1795 [error for 1797] (from a copy in the Harvard College Library). Newton's illustrations for this edition are described by Eaves in "Graphic Illustration," I, 254-256, II, 635-640. Eaves points out (I, 254-256) that Newton's designs, from which Rowlandson's etchings were executed (see the note on plate 8 , above), were almost the only ones during the period $177^{-1800}$ that emphasized the humor of $A$ Sentimental Journey. 
